\title{
PERANCANGAN LOGO RUJAK SIMPANG JODOH MEDAN
}

\author{
Sri Wahyuni Panjaitan ${ }^{1}$, Febri Yulika ${ }^{2}$, Agung Eko Budiwaspada ${ }^{3}$ \\ ${ }^{1}$ Program Studi Pascasarjana Institut Indonesia Padangpanjang, \\ ${ }^{2}$ Program Studi Antropologi Budaya Institut Indonesia Padangpanjang, ${ }^{3}$ Program Studi Desain \\ Komunikasi Visual, Fakultas Seni dan Desain, Institut Teknologi Bandung \\ 1yuniwandriani@gmail.com, ${ }^{2}$ febri.isipp@gmail.com, ${ }^{3}$ agungebw83@yahoo.com
}

\begin{abstract}
ABSTRAK
Tulisan ini membahas tentang perancangan logo Rujak Simpang Jodoh.Rujak Simpang Jodoh merupakan pusat kuliner makanan rujak tradisional, rujak tersebut dibuat dari buah-buahan yang segar dan bumbunya yang kental,salah satu ramuan bumbunya adalah pisang batu muda yang merupakan ciri khas Rujak Simpang Jodoh. Kuliner ini ada sejak tahun 1950an sampai sekarang. Rujak Simpang Jodoh ini terkenal sehingga banyak konsumen yang membeli. Tetapi belum adanya identitas yang jelas pada Rujak Simpang Jodoh ini sebagai kuliner Kota Medan, maka dari itu dilakukan branding logo Rujak Simpang Jodoh.Metode yang digunakan dalam pengumpulan data diantaranya, studi pustaka, observasi dan wawancara langsung kepada pihak yang terkait. Dari hasil analisis dari seluruh pengumpulan data dapat disimpulkan bahwa dibutuhkan identitas visual/logo bagi Rujak Simpang Jodoh. Konsep perancangan ini terdiri dari logogram dan logotype. Konsep logogram adalah sebuah cabai merah yang menangis kepedasan, sedangkan logotypenya adalah Rujak Simpang Jodoh dengan tipografi Unj-Bilquet.
\end{abstract}

Kata Kunci : Logo, Rujak Simpang Jodoh

\begin{abstract}
This paper discusses the design branding of the Rujak Simpang Jodoh. Rujak Simpang Jodoh is a traditional food, the salad is made from fresh fruits and a thick condiment, one of the marinade ingredients is a young stone banana which is typical of Rujak Simpang Jodoh. This culinary existed since the 1950s until now. Rujak Simpang Jodoh is famous so many consumers are buying. But the absence of a clear identity in Rujak Simpang Jodoh this as culinary Medan City, so that make branding of the Rujak Simpang Jodoh. The method used in collecting data among others, literature study, observation and direct interviews to the parties concerned. From the analysis of the whole data collection can be concluded that the required visual identity / branding for Rujak Simpang Jodoh. This design concept consists of logogram and logotype. The concept of logogram is a red chili that cries spiciness, while the logotype is Rujak Simpang Jodoh with Typography Unj-Bilquet.
\end{abstract}

Keywords: branding, Rujak Simpang Jodoh 


\section{PENDAHULUAN}

Seiring dengan perkembangan jaman, perkembangan dalam dunia bisnis pun ikut berkembang cepat. Perkembangan bisnis tersebut dapat dilihat dari produk produk baru yang banyak bermunculan. Salah satu identitas perusahaan yang sangat mendasar adalah logo. Logo atau simbol sangat beragam dari waktu ke waktu, dari satu perusahaan dengan perusahaan lainnya. Logo tidak memberi ruang bagi keterangan rinci tentang suatu produk image perusahaan, organisasi atau lembaga. Maka logo sering tampil dalam sosok komunikasi visual yang cukup elegan dan bermakna. Logo biasa dijadikan identitas atau tanda pengenal yang digunakan oleh perusahaan, organisasi, atau produk, untuk memberikan ciri khas yang membedakan satu perusahaan dengan perusahaan lainnya. Logo merupakan sebuah identitas, baik berupa gambar maupun stilisasi huruf, yang memuat filosofi, visi dan aspirasi perusahaan. Melalui logo pula, sebuah perusahaan ataupun organisasi berusaha menggambarkan atau menunjukkan karakteristik, kepribadian maupun budaya perusahaannya.

Umumnya logo akan menjadi senjata bisnis sangat efektif untuk meraih sasaran dan tujuan tertentu. Atau dengan kata lain melalui logo, perusahaan ingin dikenal oleh publik yang pada akhirnya mampu menciptakan citra positif atas jati dirinya. Banyak orang yang mempercayai logo yang tidak tepat, dapat menjatuhkan sebuah lembaga atau organisasi. Disinilah dapat dilihat pentingnya peranan logo bagi perusahaan, lembaga atau organisasi. Desain bentuk, komposisi warna, tipografi, dan simbol visual merupakan beberapa elemen yang terdapat dalam sebuah logo. Tiap elemen memiliki arti dan maksutersendiri yang ingin disampaikan perusahaan kepada publiknya. Pesan inilah yang akhirnya mampu membentuk citra, identitas dan budaya perusahaan. Untuk menciptakan logo diperlukan pemikiran dan pertimbangan yang matang, agar logo yang tercipta sangat mewakili karakteristik dan kepribadian perusahaan dan mampu membentuk citra positif perusahaan di mata publiknya. Keberadaan logo sangat erat kaitannya dengan citra perusahaan. Biasanya orang-orang mampu menilai seperti apa kualitas atau keprofesionalan sebuah perusahaan hanya dengan melihat logo dari perusahaan tersebut. Logo yang terkesan tegas dan dinamis menyiratkan arti bahwa perusahaan tersebut merupakan perusahaan yang profesional, terbuka, atau hangat terhadap publiknya. Sebaliknya logo yang tampak kaku dan kuno akan mengurangi kesan keprofesionalan kerja perusahaan tersebut dan juga akan tercipta kesan bahwa perusahaan tersebut tidak mengikuti zaman (up-to-date). Identitas perusahaan tidak terlepas dari citra yang melekat pada perusahaan itu. Sulit untuk mengklasifikasikan citra dan identitas sebagai subfungsi yang terpisah dalam fungsi komunikasi korporat, karena citra adalah realitas organisasi.Citra adalah apa yang terlihat di mata khalayaknya tentang perusahaan, termasuk yang dilihat khalayak pada produk, layanan, karyawan, bangunan, simbolsimbol yang digunakan, dan objek lainnya yang memberikan kontribusi terhadap realitas perusahaan. Jika organisasi tidak menyukai citra yang ada pada khalayaknya, organisasi atau perusahaan bisa mengubahnya, tetapi tidak demikian halnya dengan identitas, identitas tidak bisa diubah karena identitas adalah manifestasi visual kenyataan organisasi yang terlihat pada logo, produk, bangunan, seragam karyawan atau benda-benda lain yang digunakan organisasi atau perusahaan, dan yang dibuat oleh organisasi untuk berkomunikasi dengan khalayaknya. Identitas organisasi yang digunakan, sadar atau tidak, menciptakan citra dalam organisasi itu sendiri. Identitas ini harus selalu diperbaharui secara berkala dan selalu harus diawasi untuk disesuaikan dengan keadaan masyarakat pada saat itu kritis, dinamis, dan kreatif atau tidak. Citra dan identitas menentukan kuat atau lemahnya reputasi perusahaan. Identitas perusahaan adalah hal yang sepenuhnya merupakan citra perusahaan. Identitas perusahaan yang kuat 
menghasilkan kepercayaan orang banyak terhadap nilai dan produk perusahaan. Reputasi perusahaan akan meningkat dan pada gilirannya ini akan membantu meningkatkan identitas perusahaan. Logo bisa digunakan untuk membawa citra positif ke internal dan eksternal dengan cara yang murah serta efektif. Logo bisa dipasang dalam semua literatur, kendaraan perusahaan, atau pada semua produk. Tujuan logo adalah memberikan pengenalan seketika bahwa sesuatu merupakan milik sebuah perusahaan. Logo sebagai upaya pengenalan seketika terhadap sebuah perusahaan sangat diperlukan, lebih-lebih di era globalisasi seperti saat ini, dimana persaingan semakin ketat karena terdapat begitu banyak perusahaan yang saling berkompetisi untuk memperebutkan segmen pasar sama, sehingga menuntut perusahaan untuk membuat logo yang berbeda dan menarik bagi masyarakat. Hal ini penting karena logo berperan sebagai pembentuk persepsi pertama bagi masyarakat. Perubahan nama dan logo yang diputuskan oleh perusahaan, juga dapat menyebabkan perusahaan tersebut kehilangan identitas diri karena pergantian identitas berarti juga pergantian citra, dan citra yang sudah dibangun lama sebagai akibat adanya perubahan identitas mau tidak mau berarti juga harus diganti. Itulah sebabnya sewaktu sebuah perusahaan memutuskan atau melakukan perubahan identitas, perusahaan tersebut harus memikirkan masak-masak citra apa yang ingin ditampilkan di mata khalayaknya lewat identitas baru tersebut.

Rujak simpang jodoh merupakan rujak yang dijual dipinggiran simpang pasar 7 tembung,biasanya disebut simpang jodoh, Rujak Simpang Jodoh terkenal dengan rasanya yang enak, bumbunya yang kental, gurih karena dicampur dengan kacang, pedasnya bisa disesuaikan dengan keinginan kita. Lalu buah-buahannya juga segar. Proses penyajiannya bisa kita lihat langsung disini, mulai dari pemilihan buah apa saja yang kita mau, lalu bumbu dibuat dengan cara di uleg diatas cobek. Setelah bumbu siap, buah-buahan yang telah di potong-potong dicampur semua dalam bumbunya hingga merata. Metode yang digunakan dalam rancangan karya ini adalah metode observasi dan metode wawancara langsung yang di dasarkan atas pengalaman yang dialami secara langsung. Alasan secara metodologis bagi penggunaan pengamatan mengoptimalkan kemampuan peneliti dari segi motif, kepercayaan, perhatian, perilaku tak sadar, kebiasaan dan sebagainya, memungkinkan melihat dan mengamati sendiri dan mencatat peristiwa dalam situasi yang berkaitan dengan pengetahuan proporsional maupun pengetahuan yang langsung di peroleh dari data. Oleh karena itu, penulis secara langsung pergi ke tempat penjualan Rujak Simpang Jodoh Medan.

Metode wawancara memerlukan percakapan dengan maksdu tertentu yang dilakukan oleh dua pihak yaitu pewawancara (interviewer) yang mengajukan pertanyaan dan yang di wawancarai (interviewe) yang memberikan jawaban atas pertanyaan itu. Maksud dari mengadakan wawancara antara lain untuk mengumpulkan informasi mengenai orang, kejadian organisasi, perasaan, motivasi, tuntutan, kepedulian dan lain-lain. Metode wawancara penulis gunakan untuk mengumpulkan data secara mendalam yang dilakukakan secara formal dan non formal terhadap penjual Rujak Simpang Jodoh Medan. Sumber data ada dua : yakni data primer. Data primer di dapatkan melalui observasi langsung kelapangan dan mewawancarai beberapa orang narasumber dengan list pertanyaan yang di butuhkan..Hasil data yang di peroleh kemudian akan diolah dan dianalisa sehingga menemukan titik tentang identitas yang akan dimunculkan sehingga pencitraan Rujak Simpang Jodoh Medan dapat dihadirkan.

\section{STUDI LITERATUR}

Dalam penulisan makalah ini, penulis melakukan studi literatur pada buku-buku yang berkaitan tentang branding, tesis, jurnal dan penelitian yang telah dilakukan oleh 
pengkarya sebelumnya. Data yang di dapat dari studi literatur ini akan digunakan sebagai acuan dalam membuat karya. Berikut adalah beberapa sumber referensi.

1. Feni Yunelisa, dkk, Perancangan Identitas Visual dan Media Promosi Bukittinggi Kota Pariwisata, 2015, Jurnal e-Proceeding of Art \& Design : Vol.2, No. 2

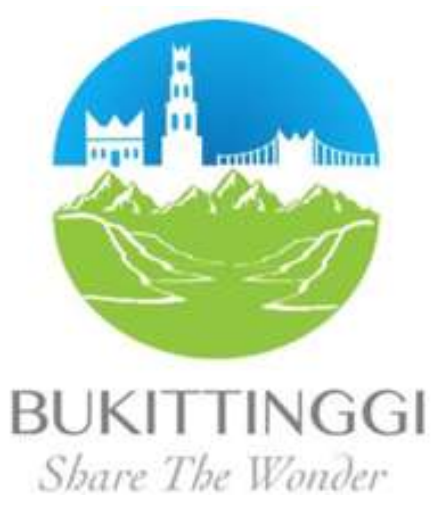

Gambar 1. Identitas Visual Bukittinggi

Perancangan Identitas Visual Kota Bukittinggi menggunakan gaya visual berupa ilustrasi. Ilustrasi yang digunakan adalah Bukit Barisan, Ngarai Sianok, Jam gadang, Jembatan Limpapeh, dan Rumah Gadang yang distilasi dalam sebuah bentuk lingkaran yang diolah menjadi satu kesatuan. Warna yang digunakan adalah warna yang dikaitkan dengan alam yaitu biru, putih, dan hijau. Biru adalah warna langit dan lautan, hijau adalah warna bukit, putih menunjukkan kedamaian, spiritualitas, kemurnian atau kesucian, kesederhanaan, kesempurnaan, kebersihan, cahaya, keamanan, persatuan. Jadi menggunakan warna putih menggambarkan bagaimana masyarakat Bukittinggi yang menjunjung agama dalam pedoman kehidupan, dan menyampaikan kesan damai dari Bukittinggi itu sendiri.

2. Rini Amadia, Perancangan Destination Branding Lembah Harau Sebagai Kawasan Ekowisata, Pascasarjana, 2017, Institut Seni Indonesia Padangpanjang.

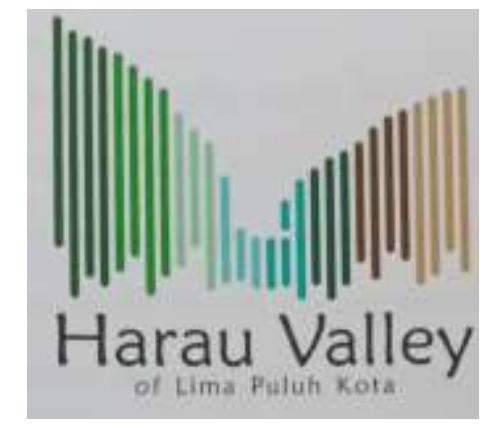

Gambar 2. Logo Lembah Harau

Destinasi Branding Harau merupakan strategi untuk penciptaan image atau identitas bagi suatu daerah dengan cara membuat positioning tersendiri. Image yang diciptakan destinasi branding objek Wisata Lembah Harau adalah sebagai kawasan ekowisata. Konsep perancangan yang digunakan untuk pembuatan logo adalah bukit 
Lembah Harau, pada perancangan ini pengkarya sebelumnya hanya menggunakan satu objek yaitu bukit yang dirancang menjadi logogram.

\section{PEMBAHASAN}

Logo memiliki banyak istilah atau pengertian yang bervariasi. Surianto Rustan (2009 : 12) dalam bukunya yang berjudul Mendesain Logo, mengungkapkan bahwa logo adalah penyingkatan dari logotype. Istilah logotype ini dikenal lebih dulu dibandingkan kata logo pada tahun 1810 - 1840. Logotype diartikan sebagai tulisan nama entitas yang didesain secara khusus dengan menggunakan jenis huruf tertentu. Sehingga logotype pada mulanya hanya memuat tulisan saja. Dari waktu ke waktu, logotype terus berkembang menjadi lebih unik dan berbeda. Logotype yanmulanya hanya memuat tulisan, kemudian ditambah dengan elemen gambar yang berbaur menjadi satu dengan tulisan. Hingga pada tahun 1937, istilah logo baru muncul hingga saat ini.

Surianto Rustan (2009 : 13) juga menjelaskan bahwa logo bisa menggunakan elemen apa saja, seperti tulisan, logogram, gambar dan ilustrasi.Sedangkan kutipan dari Design Institute of Australia yang dimuat di buku Surianto Rustan yang berjudul 'Mendesain Logo', mengungkapkan bahwa logo merupakan sebuah simbol yang digunakan untuk mengidentifikasi perusahaan tanpa adanya kehadiran nama perusahaan. Sebagai sebuah tanda visual, logo seharusnya lebih mudah untuk dikenali daripada tulisan, karena logo berisi mengenai informasi-informasi mengenai produk dan asosiasi produk. Melalui berbagai informasi dan asosiasi produk, logo menjadi sebuah sarana komunikasi untuk lebih mengenalkan atau mendapatkan pengakuan dari masyarakat atas suatu produk atau perusahaan. Menurut Terence A. Shimp (2003 : 306), tidak diragukan lagi bahwa logo menjadi peran komunikasi yang dapat berdampak pada citra dan penyadaran pada sebuah merek. Sehingga logo menjadi salah satu peran dalam strategi untuk pemasaran. Namun, Shimp (2003) juga menambahkan bahwa pada era ini, strategi yang baik dalam membentuk sebuah logo adalah dengan memilih desain yang tidak terlalu simpel juga tidak terlalu rumit. Melihat dari segi konstruksinya, logo terbagi menjadi tiga jenis, yaitu:

a) Picture mark dan letter mark

Elemen gambar dan tulisan saling terpisah, namun tetap dalam satu kesatuan.

b) Picture mark sekaligus letter mark

Elemen gambar dan tulisan saling berbaur sehingga tidak bisa dibedakan mana gambar dan mana tulisan.

c) Letter mark saja

Hanya terdapat elemen tulisan saja. Dalam penelitian ini, hal yang lebih difokuskan adalah logo yang masuk dalam jenis picture mark \& letter mark, dimana terdapat desain logo dan nama merek dalam satu kesatuan namun tidak berbaur menjadi satu. Selain logo, nama merek menjadi salah satu unsur merek yang dapat membentuksebuah merek. Menurut Shimp (2003 : 298), nama merek berguna dalam mengkomunikasikan dan memposisikan citra merek. Sehingga nama merek menjadi sangat penting dan berfungsi sebagai 'tombol' untuk mengaktifkan citra merek di pikiran konsumen. Dalam sebuah penelitian yang dilakukan oleh Dhruv Grewal di California, nama merek berisi tentang informasi yang kaya akan isyarat pembentuk citra. Begitu pula pendapat yang dikemukakan oleh Olshavsky (1985) yang ditulis Grewal dalam penelitiannya yang berjudul "The Effect of Store Name, Brand Name and Price Discount on Consumers Evaluations and Purchase Intentions". Olshavsky mencatat bahwa kualitas dari sebuah nama merek dapat berfungsi sebagai tanda dari citra merek. Seperti halnya dengan logo, nama merek juga memiliki kriteria untuk membuat nama merek yang bagus, antara lain (Shimp, 2003): 
a) Membedakan merek dari penawaran kompetitif. Sama seperti halnya dengan logo, nama merek juga harus memiliki identitas yang unik yang membedakannya dengan kompetitor.

b) Menggambarkan atribut dari merek. Nama merek yang mengesankan adalah nama merek yang secara eksplisit mengandung atribut dalam konteks suatu kategori produk. Sehingga nama merek dapat lebih mudah diingat oleh konsumen. Namun, nama merek yang berkesan juga mampu menjadi bumerang karena nama merek yang bagus tetapi tidak sesuai dengan manfaat dari merek tersebut, maka akan dinilai buruk pula.

c) Memiliki korelasi dengan unsur merek lainnya guna mencapai kecocokan dengan citra merek yang diinginkan. Nama merek yang baik, harus didukung pula dengan kebutuhan unsur merek lainnya, seperti penggunaan kemasan, logo dan lainnya.Kemasan dan bentuk logo yang sesuai dengan nama merek akan lebih meningkatkan citra merek di mata konsumen.

d) Mudah diingat dan diucapkan. Nama merek yang mudah diingat dan diucapkan berguna dalam memfasilitasi daya ingat dan pengucapannya. Pemilihan nama yang dekat dengan konsumen akan lebih mudah diingat dan dapat menjadi citra yang konkret bagi konsumen.Melalui adanya kriteria dalam pemilihan nama merek, proses yang tidak kalah penting adalah proses penamaan merek.

\section{II.1 Daya Tarik Visual}

Daya tarik secara visual mempunyai kesempatan besar dalam mempengaruhi citra merek suatu produk, karena terdapat unsur-unsur grafis yang secara visual dapat ditangkap oleh mata manusia dengan mudah. Seperti warna, merek dan huruf. Sejauh apa elemen pada unsur visual dapat membantu efisiensi dalam menyampaikan pesan, maka peneliti akan membahasnya satu persatu.

\section{II.1.1 Warna}

Sebagai suatu komponen fungsional dari penglihatan manusia, warna dapat menarik perhatian, menyejukkan atau menyakitkan mata dan berkontribusi

pada kesuksesan suatu produk dalam menarik perhatian konsumen. Penelitian yang dilakukan oleh University of Loyola, Chicago, Amerika menyatakan bahwa warna meningkatkan brand recognition hingga 80 persen. Oleh karena itu, warna menjadi proses yang penting dalam mendesain identitas visual sebuah merek. Warna juga menjadi sarana komunikasi antara produk dengan konsumen.

\section{II.1.2 Tipografi}

Elemen yang tidak kalah penting dari elemen pemilihan warna adalah tipografi. Menurut Rustan (2010 : 10), tipografi menjadi unsur vital dalam efektifitas komunikasi, baik cetak maupun elektronik. Tipografi sendiri merupakan seni dalam mengatur huruf (Kasali, 1995 : 90). Huruf dengan berbagai jenis dan gaya disebut sebagai typeface.Ada dua macam tipografi, yaitu tipografi dalam logo (letter marks) dan corporate typeface. Pada letter marks, huruf yang digunakan adalah jenis huruf yang sudah ada namun diubah bentuknya. Sedangkan corporate typeface merupakan pembuatan tulisan yang lebih bertujuan untuk menunjukkan kepribadian merek dan konsistensi identitas hingga ke elemen-elemen terkecil. Penelitian ini akan lebih banyak membahas mengenai letter marks, karena huruf yang digunakan dalam nama merek di penelitian ini menggunakan jenis huruf yang sudah ada. 


\section{II.1.3 Citra Merek ( Brand Image )}

Pengaruh antara ketertarikan logo dan nama merek dengan respon konsumen terhadapnya adalah citra merek (brand image). Shimp (2003) menjelaskan bahwa citra merek dianggap sebagai jenis asosiasi yang muncul ketika konsumen diminta untuk menyebutkan suatu merek tertentu. Citra merek terbentuk dari representasi dari seluruh persepsi konsumen terhadap merek, baik dari informasi dan pengalaman masa lalu terhadap merek itu. Hubungan konsumen terhadap suatu merek akan menjadi kuat apabila didasarkan pada pengalaman dan informasi yang didapatkan, sehingga konsumen yang memiliki citra positif terhadap suatu merek, akan lebih memungkinkan dalam melakukan pembelian (Setiadi, 2003 : 180). Menurut Glenn Walters (1974), faktor lingkungan dan personal dapat menjadi awal terbentuknya citra merek, karena faktor tersebut dapat mempengaruhi persepsi seseorang. Faktor lingkungan yang dapat mempengaruhi adalah atribut-atribut yang ada pada suatu produk yang dibuat oleh produsen. Sedangkan faktor personal yang dapat mempengaruhi adalah pengalaman yang didapatkan konsumen, suasana hati konsumen, kebutuhan serta motivasi konsumen. Faktor yang membentuk citra merek menurut Runyon (1980 : 17), berasal dari stimulus tertentu yang ditampilkan oleh sebuah produk yang menimbulkan respon pada konsumen. Ada tiga sifat stimulus yang dapat membentuk citra merek, yaitu stimulus yang sifatnya fisik (berupa atributatribut teknis dari produk), stimulus yang sifatnya psikologis (berupa nama merek) dan stimulus yang mencakup keduanya (berupa kemasan produk). Stimulus-stimulus tadi memunculkan respon dari konsumen yang berbeda-beda. Respon yang mempengaruhi pikiran seseorang yang dapat membentuk citra merek ada dua yaitu, respon rasional dan respon emosional. Respon rasional merupakan penilaian mengenai performa aktual dari merek yang dikaitkan dengan harga produk. Sedangkan respon emosional merupakan kecenderungan perasaan yang timbul dari merek.

Menurut Timmerman dalam Noble (1999), faktor dalam membentuk citra merek terdiri dari dua faktor, yaitu faktor fisik dan faktor psikologis. Faktor fisik berupa karakteristik yang ada pada merek, misalnya desain kemasan, desain logo, nama merek, fungsi dan kegunaan dari produk. Faktor psikologis berupa emosi, kepercayaan, nilai, kepribadian yang dianggap konsumen dapat menggambarkan produk dari merek tersebut.

\section{II.I.4 Rujak Simpang Jodoh}

Simpang Jodoh sendiri adalah kawasan persimpangan tempat bertemunya Jalan Besar Tembung dengan Jalan Pasar 7. Di sepanjang ruas Jalan Simpang Jodoh Pasar VII Tembung, Kabupaten Deli Serdang terdapat para penjual rujak tradisional. Bahan baku utamanya berupa buah-buahan segar dan pisang muda. Para penjual rujak buah di Simpang Jodoh Pasar 7 Tembung. Rujak Simpang Jodoh Medan telah ada sejak tahun 1950-an sampai sekarang. Dulunya penjual rujak hanya menggunakan lampu teplok. Rujak Simpang Jodoh Medan ini juga dikenal sebagai lokasi bisnis atau tempat berjualan rujak secara turun temurun. Mereka yang berjualan di tempat tersebut kebanyakan adalah masyarakat sekitar. Biasanya para penjual rujak mulai menggelar dagangannya pada sore hari dan akhirnya tutup pada malam hari sampai tengah malam.

Rujak Simpang Jodoh terkenal dengan rasanya yang enak, bumbunya yang kental, gurih karena dicampur dengan kacang, pedasnya bisa disesuaikan dengan keinginan kita. Lalu buah-buahannya juga segar. Proses penyajiannya bisa kita lihat langsung disini, mulai dari pemilihan buah apa saja yang kita mau, lalu bumbu dibuat dengan cara di uleg diatas cobek. Setelah bumbu siap, buah-buahan yang telah di potong-potong dicampur semua dalam bumbunya hingga merata. 


\section{II.I.5 Konsep Logo}

a. Konsep Visual

Rancangan logo Rujak Simpang Jodoh yang akan dihasilkan adalah berupa logogram yang mana logo tersebut akan mencirikhaskan Kota Medan yang identik dengan suku Batak walaupun di Medan banyak terdapat suku lainnya seperti suku jawa, melayu, aceh, minang dan lain sebagainya. Namun dalam logogram tersebut konsepnya adalah pedas kareka suku Batak dominan suka makanan yang pedas. Kemudian objek yang akan dibuat dalam logogram ini adalah cabai kecil merah yang menunjukkan bahwa itu sangat pedas. Cabai tersebut akan terlihat sangat kepedasan, artinya orang yang ingin membeli rujak tersebut bisa menyesuaikan tingkat kepedasannya.Selain itu logo tersebut akan mengekspresikan cabai kecil dengan mata melotot sehingga orang yang memakan rujak tersebut bisa sampai menangis.

b. Konsep Warna

Warna yang digunakan pada logogram Rujak Simpang Jodoh adalah warna merah, artinya Rujak Simpang Jodoh berada di Kota Medan yang dikenal dengan suku Batak yang memiliki warna kebudayaan yaitu merah. Sedangkan warna pendukung pada tagline logogram Rujak Simpang Jodoh adalah warna coklat, karena warna coklat tersebut diambil dari warna bumbu rujak, karena Rujak Simpang Jodoh ini terkenal dengan bumbunya yang enak, dan kental yang didalamnya terdapat pisang batu muda yang mencirikhaskan Rujak Simpang Jodoh tersebut. Selain itu warna coklat juga berarti keberanian, kekuatan, energi, gairah, semangat, dan nafsu. Sama halnya pada warna logo. Jadi, bagi orang yang memakan Rujak Simpang Jodoh tersebut akan merasa bergairah dan semangat untuk memakannya kembali.

\section{c. Tipografi}

Penggunaan huruf atau tipografi pada Logo Rujak Simpang Jodoh adalah bagian vital dari keseluruhan logo dan harus disesuaikan untuk menjaga konsistensi dan kesinambungan. Huruf atau tipografi yang digunakan adalah jenis type "Unj-Bilquet". Jenis font tersebut merupakan font yang hurufnya menyambung atau bersatu. Dimana artinya adalah antara buah dan bumbu rujak menyatu,sehingga apabila rujak tanpa buah tidak akan enak rasanya dimakan begitu juga sebaliknya ketika memakan bumbu saja akan terasa hambar jika tanpa buah.

\begin{tabular}{|c|c|c|}
\hline BRANDNAME & JENIS HURUF & STATUS \\
\hline Rujak Simpang Jodoh & Segoe Script & $\mathbf{x}$ \\
\hline Rujak Simpang Jodoh & Monotype Corsiva & $\mathbf{x}$ \\
\hline Rujok Simpong Jodoh & Bouhous 93 & $\mathbf{x}$ \\
\hline Rujak Simpang Jodoh & Cooper Black & $\mathbf{x}$ \\
\hline RUJAK SIMPANG JODOH & ALGERIAN & $\mathbf{x}$ \\
\hline
\end{tabular}




\begin{tabular}{|l|c|c|}
\hline Rujak Simpang Jodoh & FORTE & $\mathbf{x}$ \\
\hline Rujak Simpang Jodoh & Uni-Biequet & $\checkmark$ \\
\hline
\end{tabular}

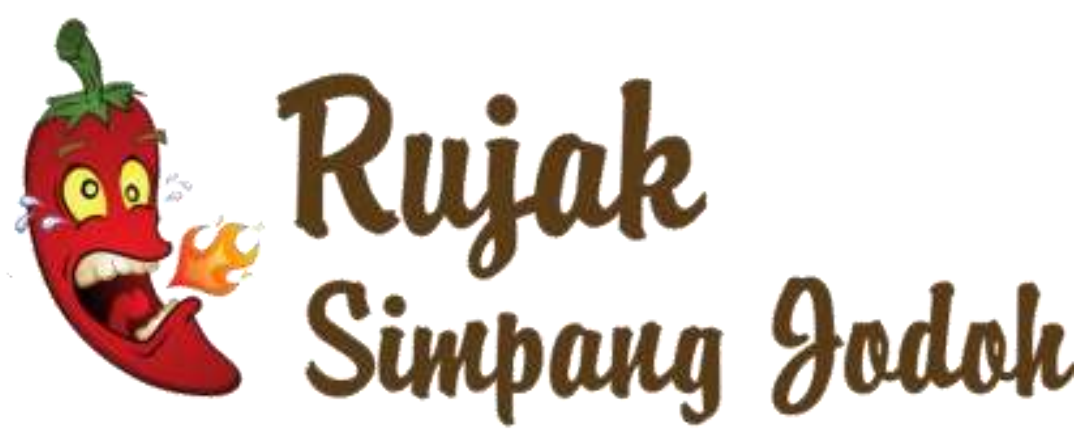

Gambar 3.Logo Rujak Simpang Jodoh

\section{II.I.6 Pengaplikasian Logo}

Pengaplikasian logo pada berbagai media berfungsi untuk mempromosikan logo Rujak Simpang Jodoh agar samapai pada target audience.

a. Kaos

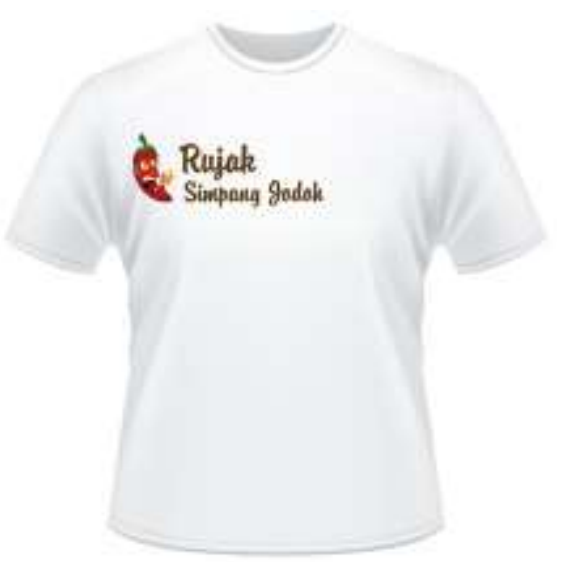

Gambar 4. Pengaplikasian pada Kaos

b. Topi

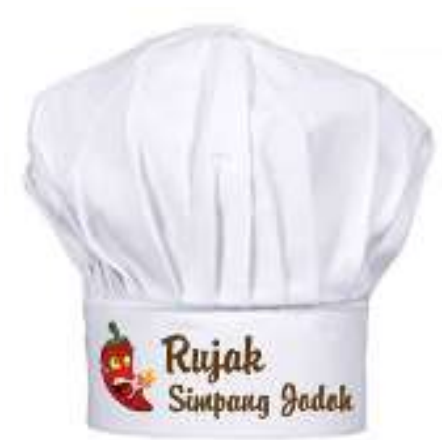

Gambar 5. Pengaplikasian pada Topi 
c. Gelas Mug

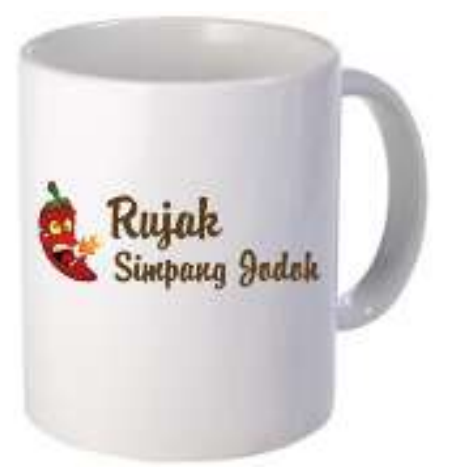

Gambar 6. Pengaplikasian pada Gelas Mug

d. Celemek

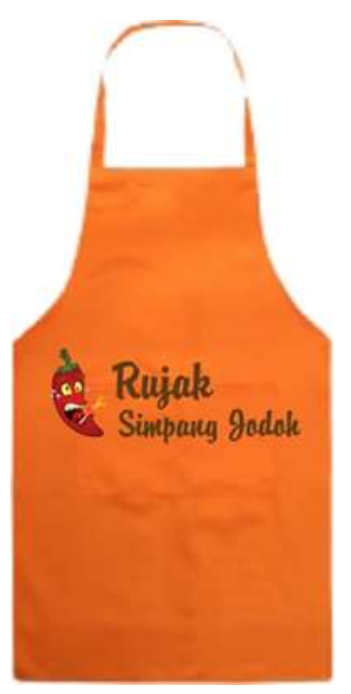

Gambar 7. Pengaplikasian pada Celemek

e. Kantong Plastik

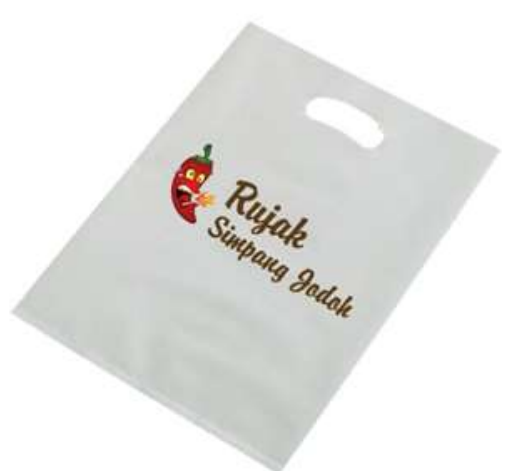

Gambar 8. Pengaplikasian pada Kantong Plastik 
f. Mangkok

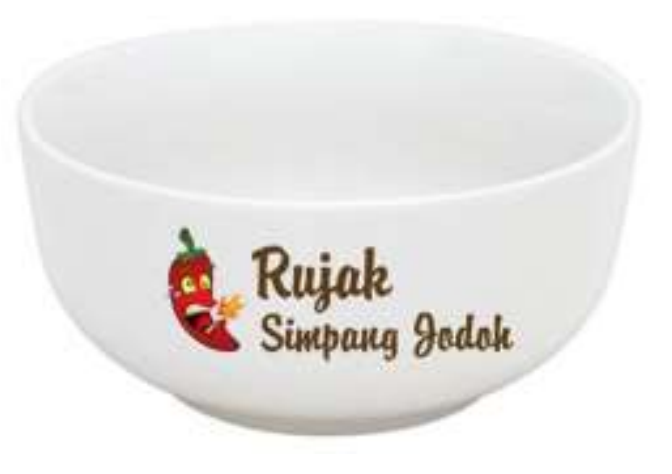

Gambar 8. Pengaplikasian pada Mangkok

\section{PENUTUP}

Dengan demikian bagi suatu perusahaan atau organisasi, logo merupakan cerminan dari nilai-nilai ideal tujuan organisasi, yang meliputi aspek: visi dan misi, ruang lingkup kerja, serta budaya perusahaan. Logo merupakan representasi dari ide-ide yang abstrak menjadi sesuatu yang nyata, dan berperan sebagai wajah dari perusahaan tersebut. Sebagai bahasa penanda, biasanya logo ditampilkan berupa simbol yang mencerminkan citra tertentu yang sengaja dibangun oleh suatu perusahaan atau lembaga.

\section{DAFTAR PUSTAKA}

\section{Buku :}

[1] Rustan, Surianto. (2009). Mendesain Logo. Jakarta: Gramedia Pustaka Utama.

[2] Shrimp, Terence A. (2003). Periklanan Promosi dan Aspek Tambahan Komunikasi Pemasaran Terpadu. Jakarta: Erlangga.

[3] Kasali, Rhenald. (1995). Manajemen Periklanan. Jakarta: Pustaka Grafiti

[4] Setiadi, N. J. (2003). Perilaku Konsumen: Konsep dan Implikasi untuk Strategi dan Penelitian Pemasaran. Jakarta: Prenada Media.

\section{Tulisan/ artikel dalam buku:}

[5] Amadia, Rini. 2017. Perancangan Destination Branding Lembah Harau Sebagai Kawasan Ekowisata : Tesis Program Pascasarjana Institut Seni Indonesia : Padangpanjang.

[6] Iskandar. (2013). City Branding Kota Padang : Tesis Program Pascasarjana Institut Seni Indonesia : Padangpanjang.

\section{Jurnal :}

[7] Nugraha, Ruchiat. Pengaruh Design Logo Baru Yang Berbasiskan Kearifan Lokal Terhadap Citra Perusahaan.Jurnal Makna Vol.5 No.1

[8] Yenata,Anita. Pengaruh Tingkat Ketertarikan pada Desain Logo dan Nama Merek Terhadap Brand Image.

[9] Yunelisa, Feni, dkk. (2015) Perancangan Identitas Visual dan Media Promosi Bukittinggi Kota Pariwisata. Jurnal e-Proceeding of Art \& Design Vol.2, No. Agustus 2015. Universitas Telkom. 